\title{
Learning of Bullying's Acts Throught Operant Conditioning
}

\author{
Ph.D. Candidate, Fitnet Hasekiu \\ "Aleksander Xhuvani" University \\ Faculty of Educational Sciences, Psychology, Elbasan, Albania \\ e-mail: neta_hasekiu@yahoo.com
}

\section{Doi:10.5901/mjss.2013.v4n9p519}

\section{Abstract}

There are different factors and ways, how the bullying's acts are learnt. The main focus of this scientific article is to analyse how are lernt the bullying's acts throught operant conditioning. After having performed bullying's acts, many students have noticed that as a result of their behavior they have managed to fulfill a specific purpose. From the analysed data in statistical way of the observations and the surveys conducted in two 9-year schools and two high schools in the city of Elbasan, it is found out that the achievement of a certain goal through bullying's acts, affects the repetition of those acts in similar situations. It is also found out that when students have avoided unpleasant situations as a result of bulling's acts, most likely they are going to perform these acts in the future to avoid other unpleasant situations. From the analysed data in statistical way it is also found out that the removal of something unpleasant through bullying's acts affects the repetition of such acts in similar situations.

Keywords: bullying's acts, operant conditioning, positive reinforcement, negative reinforcement, obversations, surveys.

\section{Introduction}

Bullying is a widespread phenomenon of concern to many students school life. Psychological and physical consequences of bullying are numerous and long in time. These effects lead to poor performance of persons involved in bullying, in emotional, social, academic and other important areas. Consequences of bullying do not feel alone in the school environment, but these consequences move also on to other social facilities. As a result of the limited literature on this phenomenon, identification of bullying's acts, prevention, mitigation and treatment of these acts do not occur in the right time and in the right way.

\section{Methodology}

Population: The phenomenon of bullying is a widespread phenomenon and concern primarily for students of the 9 - year old. Hence, theoretical population of this study is empirical scientific research is: the 9-year students in the Municipality of Elbasan.

\subsection{Sample:}

In total 600 students of the four schools, namely 150 students of the 9-year-cycle school "Harry Sule", 150 students of the 9-year-cycle school "Vasil Kamami", 150 students of the 9-year-cycle school "Xhaferr Kongoli" 150 students of the 9year-cycle schools "Naim Frasheri". Schools were selected in collaboration with the Regional Education Directorate in casual way. It became such a selection to obtain more objective data. Selection of students in terms of their background and social - economic status was made in casual way.

\subsection{Instruments:}

The instruments used in this scientific research are observation and surveys. But as the instrument which has the highest weight in this study to verify whether or not the hypothesis is the questionnaire. 


\section{Hypotheses}

The main focus of this scientific research is the process of learning of bullying's acts, mainly addressing to behaviorioral learning; especially learning through operant conditioning.

The hypothesis put forth below is based on the theory of operant conditioning learning. Operant conditioning is a form of learning in which the possibility to repeat or not a operante behavior changes as a result of its enforcement or penal consequences. Reinforcement is a consequence that increases the possibility of repeatment of a behavior that it follows. Therefore it's considered a positive reinforcer, a reinforcer that includes presentation of something pleasant, which follows a given behavior.

Taking into account the observations made and literature it can be hypothesized that:

> Fulfilling a certain goal through bullying's acts, affects the repetition of such acts in similar situations.

Also children may have noticed that when through a bullying behavior, they avoid unpleasant situations, they will most likely perform these behaviors in the future in order to avoid other unpleasant situations.

Based on the theory of learning through operant conditioning, besides positive reinforcements also exist negative reinforcements. It is considered a negative reinforcement a reinforcment consequence that involves the remove of something unpleasant that follows a given behavior. Therefore it can be hypothesized that:

$>$ Removal of something unpleasant through bullying's acts buliste affects the repetition of such acts in similar situations.

\section{Analysis}

Fulfilling a certain goal through bullying's acts, affects the repetition of such acts in similar situations.

The statistical data presented in the graph below shows that $65.5 . \%$ of the surveyed subjects claimed that they will repeat bullying's acts if they have fulfilled a certain goal through them. This shows that fulfilling a certain goal through bullying's acts, affects the repetition of such acts in similar situations.

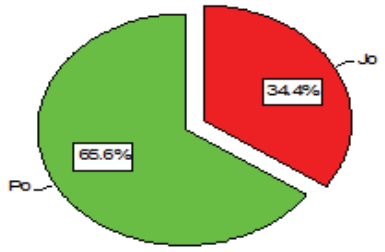

$>$ Removal of something unpleasant through bullying's acts buliste affects the repetition of such acts in similar situations.

The statistical data presented in the graph below shows that $64.3 . \%$ of the surveyed subjects claimed that they will repeat bullying's acts if they have removed something unpleasant through them. This shows that removal of something unpleasant through bullying's acts buliste affects the repetition of such acts in similar situations

\section{References}

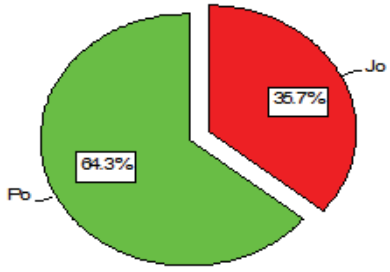

Bandura, A. (1973). Aggression: A social learning analysis. Englewood Cliffs, NJ: Prentice-Hall.

Charach, A., Pepler, D.J. \& Ziegler, S. (1995). Bullying at school: A Canadian perspective. Education Canada, 35, 12-18.

Dodge, K.A., Pettit, G.S. \& Bates, J.E. (1990). Mechanisms in the cycle of violence. Science, 250, 1678-1683.

Flammer, A. \& Alsaker, A.D. (2002). Entwicklungspsychologie der Adoleszenz. Die Erschließung innerer und äußerer Welten im Jugendalter. Bern: Huber.

Salmivalli, C., Lappalainen, M. \& Lagerspetz, K.M.J. (1998). Stability and change of behavior in connection with bullying in schools: A two-year follow-up. Aggressive Behavior, 24, 205-218. 